This is an electronic reprint of the original article. This reprint may differ from the original in pagination and typographic detail.

Author(s): Pennanen, Eveliina

Title: Hoitohenkilöstön käsitykset työyhteisön vuorovaikutuksen merkityksestä hyvinvoinnille

Year: $\quad 2015$

Version:

Please cite the original version:

Pennanen, E. (2015). Hoitohenkilöstön käsitykset työyhteisön vuorovaikutuksen merkityksestä hyvinvoinnille. Prologi : puheviestinnän vuosikirja 2015, 2015, 52-74. http://prologos.fi/prologi/index.php?page=vuosikirjat

All material supplied via JYX is protected by copyright and other intellectual property rights, and duplication or sale of all or part of any of the repository collections is not permitted, except that material may be duplicated by you for your research use or educational purposes in electronic or print form. You must obtain permission for any other use. Electronic or print copies may not be offered, whether for sale or otherwise to anyone who is not an authorised user. 


\title{
Artikkeli
}

Prologi - puheviestinnän vuosikirja 2015

\section{Hoitohenkilöstön käsitykset työyhteisön vuorovaikutuksen merkityksestä työhyvinvoinnille}

\author{
Eveliina Pennanen \\ tohtoriopiskelija, FM \\ Jyväskylän yliopisto \\ eveliina.s.pennanen@jyu.fi
}

\section{Tiivistelmä}

Sairaalaorganisaatiossa hoitohenkilöstön työhyvinvointi kohtaa monenlaisia haasteita, jotka kumpuavat sekä työn luonteesta että organisaation rakenteista ja hierarkiaverkostoista. Tämän artikkelin tavoitteena on ymmärtää työhyvinvoinnin rakentumista sairaalatyöyhteisön vuorovaikutuksessa jäsentämällä hoitohenkilöstön käsityksiä vuorovaikutuksen ja työhyvinvoinnin yhteyksistä. Tutkimusasetelma on laadullinen. Tutkimusaineistona oli yhdeksän hoitohenkilöstön jäsenen respondenttihaastattelua. Aineisto kerättiin erään suomalaissairaalan yhdestä työyksiköstä. Analyysin lähtökohtana käytettiin fenomenografisen lähestymistavan näkemystä käsityksestä: pyrkimyksenä oli ymmärtää merkityksenantojen moninaisuutta. Tutkimuksen tulokset osoittavat, että samat vuorovaikutuksen ilmiöt ja prosessit voivat rakentaa työhyvinvoinnin kokemusta kielteisen ja myönteisen ulottuvuuden näkökulmasta. Hoitohenkilöstö antaa vuorovaikutukselle erilaisia merkityksiä, ja käsitykset samoista prosesseista tai ilmiöistä voivat kytkeytyä niin hyvinvoinnin kuin pahoinvoinnin kokemuksen rakentumiseen esimerkiksi yksilön tai kontekstin mukaan. Työhyvinvoinnin rakentuminen työyhteisön vuorovaikutuksessa jäsentyykin erilaisiksi jatkumoiksi. Vuorovaikutusta ja työhyvinvointia työyhteisöissä johdettaessa ja kehitettäessä on tärkeää huomioida vuorovaikutuksessa rakentuvan työhyvinvoinnin dynaamisuus ja moniulotteisuus.

Asiasanat: hoitohenkilöstö, organisaatioviestintä, sairaala, vuorovaikutus, työhyvinvointi, työyhteisö. 


\section{Tutkimuksen tausta ja tavoite}

Hoitohenkilöstön työhyvinvointi sairaalaorganisaatioissa on koetuksella monella eri tasolla. Hoitotyön omintakeinen luonne ja sairaalaorganisaation rakenteet, kuten hierarkiat sekä erot toimintakulttuureissa ja -tavoissa jopa saman profession eri erikoisalojen sisällä, tekevät työympäristöstä kompleksin (Ang ym. 2013; Apker 2012; Barbour 2010; Wiili-Peltola 2005). Hoitohenkilöstö joutuu hallitsemaan työssään monenlaisia tehtäviä, rooleja ja tunteita; vaatimukset ja odotukset hoitohenkilöstöä kohtaan vaihtelevat, ja usein vaatimuksiin ja odotuksiin vastaamisen haasteet ilmenevät vuorovaikutuksessa (Apker ym. 2005). Jopa yli neljännes suomalaisista nuorista sairaanhoitajista harkitsee alan vaihtoa muutamia kertoja kuukaudessa tai useammin (Flinkman 2014), joten riittävän työvoiman turvaamisen kysymykset ovat sosiaali- ja terveysalan kasvaessa ja muuttuessa yhä keskeisempiä. Pelkät rakenteelliset ratkaisut eivät riitä näihin haasteisiin vastaamiseen, vaan ratkaisuksi tarvitaan tietoa ja ymmärrystä hyvinvointia tukevasta ja edistävästä vuorovaikutuksesta, jonka avulla työyhteisöjä on myös mahdollista kehittää (Mikkola ym. 2014). Työhyvinvoinnin kehittäminen on avainasemassa hoitohenkilöstön alalle saamisessa ja sitouttamisessa (Tulevaisuuden terveydenhuolto 2022). Kannustavissa ja hyvinvoivissa työyhteisöissä halutaan työskennellä tulevaisuudessakin (Mikkola ym. 2014).

Vuorovaikutus on työhyvinvoinnin kokemuksen rakentumisen keskiössä ja kytkeytyy hyvinvointiin sekä erilaisissa vuorovaikutusprosesseissa että vuorovaikutussuhteissa: Esimerkiksi hoitajien keskinäiset interpersonaaliset suhteet, yhteistyö muun henkilöstön kanssa, hoitotyön organisointi, tiimityö ja esimiehen tuki ovat keskeisiä hoitajien työhyvinvoinnin lähtökohtia (Utriainen \& Kyngäs 2009). Utriaisen (2009) mukaan sosiaalisessa yhteisössä todentuva ihmisten välinen vastavuoroisuus on hoitajien työhyvinvoinnin ydinprosessi.

Työhyvinvointia on perinteisesti lähestytty tarkastelemalla yksilön omia kokemuksia, käsityksiä ja arvioita heidän omasta työhyvinvoinnistaan, työtyytyväisyydestään tai hyvinvoinnin ulottuvuuksista työssä yleisesti (esim. Ashker ym. 2012; Jones ym. 2013; Shier \& Graham 2011; Zhang ym. 2013). Tutkimuksissa on keskitytty niin kuormitukseen ja siihen liittyviin syihin ja seurauksiin kuin hyvinvointia edistäviin tekijöihin. Työhyvinvoinnin positiivisina ulottuvuuksina on tarkasteltu esimerkiksi positiiviseen psykologiaan kytkeytyvää työn imua (Hakanen 2005). Työhyvinvoinnin rinnalla on tutkittu runsaasti työtyytyväisyyttä. Tutkimukset ovat keskittyneet työtyytyväisyyden yhteyteen työssä jaksamiseen ja 
työssä jatkamiseen: on todettu esimerkiksi, että työyhteisön suhteiden laatu vaikuttaa hoitajien työtyytyväisyyteen ja organisaatioon sitoutumiseen (Lu ym. 2012) ja että vuorovaikutuksen ongelmat työyhteisön sisällä ja eri yksiköiden välillä sekä arvostuksen osoituksen ja tuen puute heikentävät hoitajien työtyytyväisyyttä (Melo ym. 2011). Hoitajien työtyytyväisyyttä ja työhyvinvointia selittävät vuorovaikutuksen ilmiöistä ja prosesseista esimerkiksi tiimityö (Dackert 2010), palaute (Christiansen 2008), yhteistyö lääkäreiden kanssa (Tourengeau ym. 2014), hoitajien keskinäiset interpersonaaliset suhteet (Gurková ym. 2012) ja vaikutusmahdollisuudet omaan työhön (Rodwell \& Munro 2013) (ks. myös Utriainen \& Kyngäs 2009).

Työhyvinvointia heikentävinä tekijöinä tutkimusten fokuksessa ovat olleet stressi ja työuupumus (Hakanen ym. 2011; Hayes ym. 2010; Kanste 2011). Hoitajien työssä vuorovaikutukseen kytkeytyviksi stressitekijöiksi on todettu esimerkiksi työyhteisön interpersonaalisissa suhteissa ilmenevät ongelmat, kuten hoitajien ja lääkäreiden väliset konfliktit ja yhteistyön heikkous sekä potilaan hoidosta päätettäessä lääkäreiden osoittama arvostuksen puute hoitajien mielipiteitä ja osallistumista kohtaan (Nakakis \& Ouzouni 2008). Hyvinvoinnin edistämisen lisäksi lääkäri-hoitajasuhteen tukeminen, hoitajien osallistaminen sairaalan päätöksentekoon ja johdolta saatu tuki ovat tärkeitä tekijöitä hoitotyön laatua kehitettäessä (Krueger ym. 2013).

Aiemmissa tutkimuksissa on siis todettu, että vuorovaikutus kytkeytyy kokemukseen hyvinvoinnista ja pahoinvoinnista työssä. Vuorovaikutus on nähty tutkimuksissa muuttujana, mutta vuorovaikutusta ei ole lähestytty työhyvinvoinnin kokemusta rakentavana prosessina. Tässä tutkimuksessa lähtökohtana työhyvinvointiin on EU-Proggress-hankkeen määritelmä: "Työhyvinvointi tarkoittaa turvallista, terveellistä ja tuottavaa työtä, jota ammattitaitoiset työntekijät ja työyhteisöt tekevät hyvin johdetussa organisaatiossa. Työntekijät ja työyhteisöt kokevat työnsä mielekkääksi ja palkitsevaksi, ja heidän mielestään työ tukee heidän elämänhallintaansa.” (Anttonen \& Räsänen 2009, 18.) Työhyvinvointi nähdään tässä tutkimuksessa työyhteisön vuorovaikutuksessa rakentuvana ja ylläpidettävänä ilmiönä (ks. Mikkola ym. 2014) ja tarkastelu kohdistuu hoitohenkilöstön käsityksiin vuorovaikutusprosessin tasolla työyhteisössä. Käsityksiä tarkastelemalla voidaan kuvata vuorovaikutukselle annettavia samanlaisia tai erilaisia merkityksiä ja siten syventää ymmärrystä työhyvinvoinnista vuorovaikutuksessa rakentuvana ilmiönä (ks. esim. Huusko \& Paloniemi 2006). Tämän tutkimuksen tavoitteena on ymmärtää työhyvinvoinnin rakentumista sairaalatyöyhteisön vuorovaikutuksessa jäsentämällä hoitohenkilöstön käsityksiä vuorovaikutuksen ja työhyvinvoinnin yhteyksistä. 
Artikkelin tutkimuskysymys on: Millaisia käsityksiä hoitohenkilöstöllä on työyhteisön vuorovaikutuksen merkityksestä työhyvinvoinnille?

\section{Tutkimusaineisto ja -menetelmät}

\section{Aineisto}

Artikkelin tutkimusasetelma on laadullinen. Tutkimusaineistona on yhdeksän hoitohenkilöstön jäsenen respondenttihaastattelua. Hoitohenkilöstöllä tarkoitetaan tässä tutkimuksessa eritasoisia ja erilaisissa tehtävissä sairaalassa työskenteleviä hoitajia sekä tiiviisti hoitotyötä tukevaa työtä, kuten ajanvarauksia ja asiakasneuvontaa, tekeviä työntekijöitä. Respondenttihaastatteluissa on tavoitteena saada avoimia tai rajaamattomia vastauksia ja tyypillistä on, että haastateltavia pyydetään kuvaamaan itseään, jotakin ongelmaa tai tilannetta tai selittämään sitä, kuinka he näkevät oman sosiaalisen maailmansa (Lindlof \& Taylor 2002, 178-179). Aineisto on kerätty syksyllä 2013 erään suomalaissairaalan yhdestä työyksiköstä osana Sairaalatyöyhteisön työhyvinvointia rakentavat vuorovaikutuskäytänteet -tutkimushanketta.

Tutkitusta työyhteisöstä haastateltaviksi valikoituivat vapaaehtoisiksi haastateltaviksi ilmoittautuneet hoitohenkilöstön jäsenet. Haastateltaviksi suostuneet jättivät yhteystietonsa suljettuun, tutkimushankkeen tutkijoiden säännöllisin väliajoin tyhjentämään laatikkoon työpaikan taukotilassa tai ottivat tutkijoihin sähköpostitse yhteyttä, minkä jälkeen haastatteluaika ja -paikka sovittiin. Haastateltavia informoitiin sekä suullisesti että kirjallisesti tutkimuksesta ja sen päätavoitteista, ja he allekirjoittivat kirjallisen suostumuslomakkeen tutkimukseen osallistumisesta. Haastatteluun osallistuminen oli vapaaehtoista, ja haastateltavilla oli mahdollisuus vetäytyä tutkimuksesta tutkimuksen missä tahansa vaiheessa. Haastateltavista seitsemän oli koulutukseltaan sairaanhoitajia ja kaksi muun, esimerkiksi toimistotyöhön liittyvän, koulutuksen saaneita. Haastateltavat olivat noin 40-60-vuotiaita, ja heidän työkokemuksensa hoitoalalla vaihteli muutamasta vuodesta noin kolmeenkymmeneen vuoteen. Naisia haastateltavista oli viisi ja miehiä neljä.

Haastattelukysymysten teemoina olivat työyhteisön rakentuminen, vuorovaikutus työyhteisössä, valta sekä työhyvinvointi ja vuorovaikutus. Yksi haastattelu kesti noin tunnin, ja haastatteluiden kokonaiskesto oli 10 tuntia 39 minuuttia. Haastattelut tallennettiin, ja ne litteroitiin kirjalliseen muotoon sanatarkasti. Haastateltavien anonymiteetin turvaamiseksi artikkelissa esitetyistä aineistoesimerkeistä on poistettu tunnistetiedot, kuten erikoisalojen ja hoitotoimenpiteiden nimet. 


\section{Analyysi}

Aineiston analyysin lähtökohtana oli fenomenografisen tutkimuksen näkökulma käsityksestä: käsitykset ovat merkityksenantoprosesseja, joille annetaan syvempiä ja laajempia merkityksiä kuin mielipiteille (Huusko \& Paloniemi 2006, 164). Analyysin keskiössä on erilaisten kokemusten, käsitysten tai ymmärrysten laadullinen kuvaaminen, joka pohjautuu ihmisten kuvauksiin tietystä ilmiöstä tai heitä ympäröivästä maailmasta. Näin pyritään ymmärtämään ihmisten erilaisia käsityksiä ja näiden keskinäisiä suhteita ja laadullisia eroja. (Hasselgren \& Beach 1997; Marton \& Pong 2005.) Tässä tutkimuksessa tutkimuksen lähestymistapa on fenomenografisen suuntauksen tapaan aineistolähtöinen: empiirinen aineisto on kategorisoinnin perusta, eikä teoria toimi luokittelun runkona (Huusko \& Paloniemi 2006, 166). Fenomenografista lähestymistapaa noudatellen kategorisointi toteutettiin horisontaalisena, jolloin kategorioilla ei pyritä kuvaamaan niiden keskinäistä paremmuutta, vaan erilaiset kategoriat nähdään samanarvoisiksi tai yhtä tärkeiksi (Järvinen \& Järvinen 2011, 84).

Analyysissa aineistoa käsiteltiin kokonaisuutena, ei yksittäisten haastateltavien vastauksina. Aineiston analyysi toteutettiin kolmivaiheisena fenomenografisen analyysin lähtökohtia noudatellen: analyysissa etsittiin merkitysyksiköt sekä muotoiltiin ensimmäisen, toisen ja kolmannen tason kategoriat, mutta ei pyritty kuvauskategoriajärjestelmän luomiseen (ks. Huusko \& Paloniemi 2006). Analyysissa hyödynnettiin laadullisen tutkimusaineiston analyysiin soveltuvaa ATLAS.ti-ohjelmaa (ks. Friese 2014).

Analyysin ensimmäisessä vaiheessa aineistosta tunnistettiin kohdat, joissa puhutaan vuorovaikutuksesta ja työhyvinvoinnista työyhteisössä. Analyysiyksikkönä käytettiin merkityskokonaisuutta. Merkitysyksiköt eroteltiin ja nimettiin niiden sisältöä kuvanneilla koodeilla. Merkitysyksiköt jäsentyivät haastattelujen teemoja mukaillen aineistolähtöisesti. Koodeja muodostui neljätoista: haastava vuorovaikutus, johtaminen, kuuluminen, lääkäri-hoitajasuhde, muodollinen ja epämuodollinen vuorovaikutus, osallistuminen, osastokokous, palaute, sairaalahierarkia, tieto, tuki, työyhteisö, valta ja vertaisuus. Toisessa vaiheessa näistä ensimmäisen tason kategorioista alettiin jäsentää ja ryhmitellä toisen tason kuvauskategorioita (Huusko \& Paloniemi 2006; Järvinen \& Järvinen 2011), joissa etsittiin yhdistäviä tekijöitä tarkastelemalla, millaisia erilaisia käsityksiä samoista ilmiöistä tuotetaan. Toisen tason kategorioiksi muodostuivat kuuluminen, yhteistyö, vaikuttaminen, tuki ja tiedonhallinta. Kolmannessa vaiheessa näistä kategorioista tunnistettiin, millaiseksi niissä kuvat- 
tiin vuorovaikutuksen merkitystä työhyvinvoinnille, jolloin kategorioiksi muodostuivat hyvinvoinnin kokemusta ja pahoinvoinnin kokemusta rakentava vuorovaikutus kuulumisen, yhteistyön, vaikuttamisen, tuen ja tiedonhallinnan merkityksissä.

\section{Tulokset}

Tämän tutkimuksen tavoitteena oli ymmärtää työhyvinvoinnin rakentumista sairaalatyöyhteisön vuorovaikutuksessa jäsentämällä hoitohenkilöstön käsityksiä vuorovaikutuksen ja työhyvinvoinnin yhteyksistä. Tutkimuskysymyksenä oli: Millaisia käsityksiä hoitohenkilöstöllä on työyhteisön vuorovaikutuksen merkityksestä työhyvinvoinnille?

Hoitohenkilöstön käsitykset työyhteisön vuorovaikutuksesta jäsentyvät sekä työhyvinvointia tukeviksi että työhyvinvointia heikentäviksi merkityksiksi: sama vuorovaikutusprosessi tai -ilmiö voi rakentaa sekä hyvinvoinnin että pahoinvoinnin kokemusta. Työhyvinvointi näyttäytyykin hoitohenkilöstön käsityksissä vuorovaikutuksessa rakentuvana ilmiönä, jossa vuorovaikutuksen prosesseja ja ilmiöitä ei voida yksiselitteisesti luokitella työhyvinvoinnin kannalta myönteisiksi tai kielteisiksi, vaan nämä molemmat ulottuvuudet voivat olla osa samaa prosessia tai ilmiötä. Merkitykset voivat kiinnittyä sekä yksilö- että yhteisötasolle eli ilmiöiden nähdään rakentavan kokemusta joko yksilön, yhteisön tai näiden molempien hyvinvoinnista tai pahoinvoinnista. Hoitohenkilöstön käsitykset työyhteisön vuorovaikutuksen merkityksestä työhyvinvoinnille jäsentyvät kategorioihin kuuluminen, yhteistyö, vaikuttaminen, tuki ja tiedonhallinta.

\section{Kuuluminen}

Yhteisöön tai ryhmään kuulumisen merkitykset jakautuvat ulottuvuuksiin, joissa merkityksellistä työhyvinvoinnin kokemuksen rakentumiselle on kuuluminen työyhteisöön tai vertaisryhmään, jääminen yhteisön tai ryhmän ulkopuolelle sekä jättäytyminen ryhmän ulkopuolelle.

Hyvinvoinnin kokemusta rakentaa vuorovaikutus, jossa syntyy kokemus kuulumisesta työyhteisöön. Työyhteisöön kuulumisen tunne on hoitohenkilöstön mukaan edellytys toimivalle yhteistyölle suoritettaessa sairaalassa perustehtävää, jossa jokaisella työyhteisön jäsenellä on oma tehtävänsä. Työyhteisöksi hoitohenkilöstö määrittelee oman työyksikkönsä ja sen kaikki työntekijät.

Erilaisia merkityksiä sen sijaan saa kuuluminen vertaisryhmään, jonka hoitajat käsittävät oman erikoisalansa hoitajien ryhmäksi. Tunne vertaisryhmään kuulumisesta voi rakentaa hyvinvoinnin kokemusta: kuulumi- 
nen ja osana oleminen voivat tukea jaksamista. Jos yksilö kokee vertaisryhmään kuulumisen itselleen ja hyvinvoinnilleen merkitykselliseksi, vertaisryhmän ulkopuolelle jääminen tuottaa kokemusta pahoinvoinnista. Omasta halusta vertaisryhmän ulkopuolelle jättäytyminen puolestaan voi rakentaa hyvinvoinnin kokemusta. Haastateltavat käsittävät, että kaikilla työyhteisön hoitajilla on mahdollisuus kuulua hoitajien vertaisryhmään, mutta erilaisiin alaryhmiin jäseneksi pääseminen voi olla haastavampaa. Alaryhmiä muodostavat esimerkiksi saman ikäiset hoitajat tai yhteisen työhistorian jakavat työntekijät. Ulkopuolelle jättäytymisen koetaan rakentavan kokemusta hyvinvoinnista etenkin erilaisten alaryhmien kohdalla. Toiset näkevät, että alaryhmät heikentävät yhteisöllisyyttä erottelemalla työyhteisöä liiaksi erilaisiin ryhmiin, niin sanottuihin kuppikuntiin. Toisille alaryhmät puolestaan ovat hyvinvointia edistäviä tekijöitä mahdollistamalla tuen antamisen ja vastaanottamisen pienemmissä ryhmissä.

Kuulumisen merkitykset omalle ja muiden työntekijöiden työhyvinvoinnille käsitetään eri tavoilla. Esimerkiksi jonkin alaryhmän ulkopuolelle jättämisen merkitystä ei omalta osalta koeta hyvinvointia heikentäväksi, mutta koetaan, että ulkopuolelle jättäminen voi olla kuormittavaa joillekin muille työyhteisön jäsenille. Ilmiö siis tunnistetaan osaksi työhyvinvoinnin kokemuksen muodostumista työyhteisössä, vaikka se ei vastaisikaan omaa kokemusta. Tässä aineistoesimerkissä kuvataan ulkopuolelle jättämisen merkitystä:

H5: En mä omalle kohalle. Mä oon ollut niin kauan, että mulla on semmoset omat kaverit, ja mä elän erilaista elämänvaihetta mitä nää nuoret. Mutta silleen, että kun kaikkia niitä nuoria keitä täällä on, ei hyväksytä siihen samoihin piireihin, niin sitten tuntuu, että kun sivusta kuulee, että - - - niin miksi ei oo hän päässyt siihen mukaan. Niin se tuntuu niinkun itestä kurjalta. Varmaan se, kun on itellä lapsia, ja jos on nähnyt niillä sen, että jotkut kaverit ei otakaan mukaan. Mutta toisaalta taas aattelee, että näittehän pitäis olla jo aikuisia kaikki.

Hoitohenkilöstö rakentaa ja ylläpitää vertaisryhmään kuulumisen tunnetta erityisesti työtilanteiden ulkopuolisessa vuorovaikutuksessa, kun esimerkiksi tauoilla kokoonnutaan yhteen vertaisten kesken reflektoimaan työssä tapahtuneita tilanteita. Vuorovaikutuksella voidaan osoittaa ryhmään kuulumista ja kuulumattomuutta. Seuraavassa aineistoesimerkissä kuvataan vertaisryhmään kuulumisen tunteen tuottamista työyhteisön vuorovaikutuksessa: 
H3: Että jos meidän hoitajat tekee potilaan hoitoon liittyvät työt joita [erikoisala]-hoitaja ei osannut tehdä, tai ei vaan oo tehnyt, niin sitten muut meidän hoitajat kehuu, että taas [oman erikoisalan nimi]-hoitajat näyttää, miten homma hoituu. Vaikka nyt tekee jonkun ihan aika yksinkertaisen homman, kuten - - -

\section{Yhteistyö}

Yhteistyö jäsentyy hoitohenkilöstön käsityksissä jatkumolle työntekijöiden tasavertaisuus - työntekijöiden eriarvoisuus. Tasavertaisuuden ilmaisemisen ja siitä syntyvän kokemuksen kaikista työntekijöistä osana samaa työyhteisöä nähdään rakentavan toimivaa yhteistyötä ja sitä kautta hyvinvoivaa työyhteisöä. Toisaalta tasavertaisuus ei aina tuota hyvinvoinnin kokemusta, vaan haastateltavien mukaan joissakin sairaalan työtilanteissa työntekijöillä on oltava eritasoisia positioita. Esimerkiksi elvytystilanteessa tasavertaisuuden kokemusta merkityksellisempänä on tehtävä ja pyrkimys sen onnistuneeseen suorittamiseen; oleellista on viestiä kaikkien työntekijöiden tietävän oman paikkansa, tehtävänsä ja vastuunsa. Mahdollisen tehokkaasti tavoitteen saavuttamiseen pyrkivä vuorovaikutus tukee tällöin hyvinvoinnin kokemuksen rakentumista. Samankaltaisen vuorovaikutuskäytänteen siirtyminen muihin työyhteisön vuorovaikutustilanteisiin voi kuitenkin kuormittaa, jos vuorovaikutuksessa osoitetaan ylemmyyttä tai alemmuutta silloin, kun se ei ole tarkoituksenmukaista.

Hierarkian teemat näkyvät tasavertaisuuden ja eriarvoisuuden jatkumolla. Haastateltavat käsittävät sairaalan hierarkkisuuden tulevan näkyväksi työyhteisön vuorovaikutuksessa. Hierarkkisuus ilmenee työntekijöiden ja johdon tavoissa osoittaa suhtautumistansa tai viestiä asemaansa ja positioida siten myös viestintäkumppaninsa erilaisiin asemiin. Hierarkkisuuden ei itsessään koeta rakentavan kokemusta hyvinvoinnista tai pahoinvoinnista, vaan pikemminkin sen käsitetään olevan osa sairaalakulttuuria. Hierarkkisuuden ilmaisemisen tavat vuorovaikutuksessa kuitenkin saavat erilaisia merkityksiä, jotka nousevat esiin erityisesti lääkäri-hoitajasuhteessa. Vuorovaikutus, jossa lääkäri ja hoitaja rakentavat yhteistyötä, tuottaa hyvinvoinnin kokemusta. Kokemusta pahoinvoinnista puolestaan muodostaa vuorovaikutus, jossa toimivaksi koettua yhteistyötä ei synny tai yhteistyöhön ei pyritä. Yhteistyötä ei rakennu silloin, kun lääkäri vain käskee ja hoitaja toimii käskyn mukaisesti, ellei kyseessä ole esimerkiksi elvytystilanteen kaltainen tilanne, jossa selkeät toimintaohjeet ja -vastuut ovat tärkeitä. Yhteistyön merkityksissä lääkäri-hoitajasuhteessa hyvinvointiin kytkeytyväksi vuorovaikutukseksi kuvataan molemminpuolinen mahdollisuus oppia ja opettaa, mahdollisuus neuvotella sekä mahdolli- 
suus saada lääkäreiltä palautetta. Myös hoitajien ja eri osastojen välisen yhteistyön nähdään olevan merkityksellistä työhyvinvoinnin kannalta. Seuraavassa aineistoesimerkissä puhutaan lääkäriltä saatavan palautteen merkityksestä hyvinvoinnille:

H5: Niin, tai sitten joskus jossain hälytystyössä kun käy ja tulee joku elvytystilanne tai joku, niin jos sit se lääkäri sanoo sen jälkeen, että sulla meni tosi hyvin putkeen. Että hyvin hoidettiin tää homma. Että tulee semmonen me-henki siihen, vaikka ollaan eri ammattiryhmän edustajia. Niin semmonen antaa semmosen tunteen, että mää lähen uudestaankin tekemään tuota.

Tasavertaisuuden ja eriarvoisuuden jatkumolla yhteistyön toimivuuteen tai toimimattomuuteen kytketään sairaalan työkulttuuri ja siinä tapahtuneet muutokset. Nuorilla työntekijöillä voi olla erilaisia odotuksia ja oletuksia tasavertaisesta työyhteisöstä kuin vanhemmilla työntekijöillä. Kahdessa seuraavassa aineistoesimerkissä haastateltavat kuvaavat tätä ilmiötä:

H1: No se ehkä näkyy sillein, mä en tiiä onks tää oikee sana, se näkyy ehkä tämmösenä kyykyttämisenä. Varsinkin vanhempien, vähän vanhempien lääkäreitten taholta, jotka on pitempään tehny ja on ehkä noita vanhan ajan läkäreitä. Erot on sillon ollu selkeämmät hoitajan ja lääkäreitten välillä. Nuorempien lääkäreitten kanssa ei niinkään. Ehkä ihan taloon tulleet vähän kokeilee siipiään niin sanotusti, mutta ne sitten kyllä kolahtaa maahan, että tässä ollaan kuitenkin saman työn ääressä ja samaa työyhteisöä. Yhdessä pitäis pystyä töitä tekemään.

H7: Ennen se oli rasittavampaa tää työ, ja ihmistenväliset suhteet oli paljon kireempiä. Ja lääkäreitten ja hoitajien väliset suhteet oli ihan eri tasolla. Nythän tässä kun kattelee, siinäkin kun lääkärit tulee tuohon jutteleen ja keskusteleen, tää on ihan tämmöstä tasa-arvosta. Niinkun nuorempien kans onkin. Sitten täällä on niitä vanhempia, ja sitten kun tulee uus lääkäri, se opetetaan tavoille sit heti: "Sä oot lääkäri, etkä mikään hoitaja." Tää vähän semmosta kitkaa aiheuttaa, mutta ei se minua haittaa ainakaan yhtään.

\section{Vaikuttaminen}

Vaikuttaminen kytkeytyy hoitohenkilöstön käsityksissä työhyvinvointiin kahdesta eri näkökulmasta: tunne vaikuttamisen mahdollisuudesta voi rakentaa kokemusta hyvinvoinnista, mutta hyvää vointia voi myös luoda 
tunne siitä, että ei tarvitse vaikuttaa itse, vaan joku muu vaikuttaa muiden puolesta - vastuu on jollakin toisella. Vaikuttamisella tarkoitetaan tässä yhteydessä esimerkiksi omaan työhön tai työyhteisöön liittyviin asioihin vaikuttamista.

Hoitohenkilöstö käsittää vaikuttamisen mahdollisuuksien työyhteisössä olevan tasaveroiset tai näennäisesti tasaveroiset, mutta tietynlainen asema yhteisössä voi edistää vaikutusmahdollisuuksia. Asema voi määräytyä työntekijän koulutuksen, kokemuksen tai muodollisen aseman kautta. Myös persoonan ja vuorovaikutustaitojen, kuten taidon ottaa puheenvuoroja ja argumentoida, käsitetään kytkeytyvän parempiin vaikutusmahdollisuuksiin. Kahdessa seuraavassa aineistoesimerkissä kuvataan vaikuttamisen mahdollisuuksia työyhteisön vuorovaikutuksessa:

H3: No täällä kovaääniset, fiksut ja kokeneet hoitajat saavat äänensä kuuluviin, mutta mä luulen, ettei heillä kuitenkaan sitten ole hirveen paljon sitten enemmän valtaa kuin niillä hiljaisilla kuitenkaan. Se demokratia jotenkin toimii. Tai mä en huomaa sitä.

H7: Toisia kuunnellaan enempi ja toisia vähempi. Mutta kyllä mä sanon, että joku nuorempikin hoitaja, tullu koulusta just, fiksuja mielipiteitä niin kuin heillä on, ja uskaltavat sen tuoda esille, niin kyllä heitäkin varmaan kuunnellaan. Ja jopa voi johtaakin johonkin toimenpiteeseen tai muutokseen. Mutta se on hyvin pientä. Mutta enemmän on äänessä vanhemmat ja kokeneemmat niissä kokouksissa. Ja joitten mielipiteitä sitten enemmän kuunnellaan.

Myös vertaisryhmän merkitys nousee esiin käsityksissä, joissa vaikuttaminen kytketään työhyvinvointiin. Vertaisryhmän tuella käsitetään olevan merkitys rohkeuteen pyrkiä vaikuttamaan, kun mahdollinen johdon tai muiden työntekijöiden kielteinen suhtautuminen ehdotettuun asiaan ei kohdistu yhteen työntekijään, vaan mukana on ryhmän kollektiivinen tuki. Tällöin mahdollinen epäonnistumisen tai torjutuksi tulemisen kokemus jaetaan yhdessä muiden kanssa, minkä nähdään tukevan hyvinvoinnin kokemuksen rakentumista.

Vaikka tasapuolisten vaikutusmahdollisuuksien koetaan tuottavan kokemusta hyvinvoivasta työyhteisöstä, kaikki eivät koe merkitykselliseksi päästä itse vaikuttamaan asioihin. Hyvinvoinnin kokemusta voi tuottaa myös se, että työntekijän ei tarvitse vaikuttaa, vaan joku muu vaikuttaa ja kantaa vastuun työntekijän puolesta. Tällöin nähdään tärkeäksi, että organisaation erilaisissa hallinnollisissa ryhmissä, kuten johto- ja suunnittelu- 
ryhmissä, on edustajina oman ammattiryhmän jäseniä. Edustuksellisuus kytkeytyy näin osaksi hyvinvoinnin kokemusta rakentavaa vuorovaikutusta työyhteisössä. Hyvinvoinnin kokemuksen rakentumiselle merkityksellisenä näyttäytyy yksilön mahdollisuus valita, vaikuttaako vai ei.

\section{Tuki}

Tuen merkitykset jäsentyvät jatkumolle tarkoituksenmukainen tuki - juuttuminen kielteisten seikkojen käsittelyyn. Juuttumisella kielteisten seikkojen käsittelyyn tarkoitetaan ilmiötä, jossa vuorovaikutuksessa ylläpidetään kielteisiä seikkoja käsittelemällä yhdessä samoja kielteisiä asioita, ongelmia tai tunteita jatkuvasti (Rose 2002). Hoitohenkilöstö käsittää tuen sekä emotionaalisena että tiedollisena tukena. Tarkoituksenmukaisen tuen ulottuvuuksina hoitohenkilöstön käsityksissä ovat hyvinvointia tuottava riittävä tuki ja kuormitusta aiheuttava liialliseksi koettu tuki, joka näyttäytyy henkilöstölle esimerkiksi neuvomisena työtilanteissa silloin, kun neuvoja ei koeta tarvittavan.

Emotionaalinen tuki käsitetään hyvinvoinnin kokemusta rakentavaksi ilmiöksi silloin, kun yksilö kokee merkitykselliseksi saada tukea haastavien työtilanteiden jälkeen työyhteisön muilta jäseniltä tai silloin, kun yksilö kaipaa tukea työn ulkopuolisen elämän kysymyksiin. Tukea kaivataan työtilanteissa, joissa potilaiden haastavat tilanteet ja tunteet kuormittavat myös hoitajaa. Tukea tuottavaksi vuorovaikutukseksi nähdään kuormittavien tai haastavaksi koettujen tilanteiden ja tunteiden käsittelyn mahdollisuus työyhteisön sisällä, kuten seuraavassa aineistoesimerkissä kuvataan:

H6: Tai se potilaan kohtaaminen. Että kyllä jotenkin tuntuu, että tarttis enemmänkin semmosta tukea, kun että mitä enemmän sää annat noille asiakkaille, niin sen tyhjempi sää itse oot. Että on työtilanteessa, missä ne asiakkaat vuodattaa, ihan kuin jossain uimahallin saunassa. Siellähän ne ihmiset kertoo asioita, mitä ei ikinä jollekin vieraalle kerrottais missään kauppajonossa. - - - Ja sitten kun sä koetat tukea sitä asiakasta ja hänen asioitaan niinkö eteenpäin, ja sitten kun se tilanne on ohi, sulla alkaa het perään seuraava uus. Niin ois joskus ihan hyvä, että sitä sais purkaa johonkin, eikä vaan nielasta ja koittaa unohtaa ja lähteä kotiin. Että miten jollakin on elämä hajonnut.

Kuormittavien ja haastavien tilanteiden ja tunteiden käsittely voi myös näyttäytyä pahoinvoinnin kokemusta tuottavana prosessina, jos vuorovaikutus nähdään yksilöä tai yhteisöä kuormittavana juuttumisena kielteisten seikkojen käsittelyyn. Raja kielteisten asioiden käsittelyn ja niihin 
juuttumisen välillä on hoitohenkilöstön käsityksissä vaihteleva. Joillekin on hyvinvoinnin kannalta tärkeää käsitellä ongelmat ja haastavat tunteet yhdessä huolellisesti ja toistuvasti, kun taas toiset kokevat käsittelyn juuttumisena kielteisiin seikkoihin. Yksilölliset erot tulevat esiin myös siinä, miten, millaisissa tilanteissa ja millaisilla tavoilla tukea nähdään merkitykselliseksi antaa ja saada.

Tarkoituksenmukainen tiedollinen tuki muilta työyhteisön jäseniltä nähdään hyvinvoinnin kannalta oleelliseksi jatkuvasti muuttuvassa työssä, jossa tiedolla ja sen omaksumisella on keskeinen merkitys tavoitteiden saavuttamiseksi. Tiedollista tukea saadaan etenkin toisilta hoitajilta ja toisaalta opettamisen ja ohjauksen näkökulmasta myös lääkäreiltä. Eritaustaisten työntekijöiden nähdään olevan tärkeä resurssi tiedollisen tuen prosesseissa; pitkään alalla työskennelleet saavat tiedollista tukea tuoreen osaamisen ja erilaisten näkökulmien muodossa vastavalmistuneilta, ja vähemmän aikaa alalla toimineet voivat hyötyä kokeneiden työntekijöiden osaamisesta ja asiantuntijuudesta. Jos tuen antaminen näyttäytyy liiallisena neuvomisena, hyvinvoinnin kokemusta ei synny, vaan vuorovaikutus nähdään pikemminkin yksilön ammattitaidon kyseenalaistamisena. Sairaalan hierarkiat näkyvät tiedollisen tuen merkityksissä, sillä etenkään kokeneemman tai korkeammin koulutetun työntekijän työhön ei mielellään puututa, ellei toinen osapuoli itse pyydä neuvoa tai apua. Epävarmoissa ja uusissa työtilanteissa tuella käsitetään olevan erityisen suuri merkitys työhyvinvoinnille.

\section{Tiedonhallinta}

Tiedonhallinnan merkitykset jakautuvat jatkumolle tarve saada tietoa - tiedonhallinnan haasteet. Hoitohenkilöstöllä on toisaalta tarve ja halu saada tietää mahdollisimman paljon omaan työhönsä, työyhteisöönsä ja organisaatioonsa liittyvistä asioista, mutta liian suuren ja hankalasti hallittavissa olevan tietomäärän koetaan kuormittavan.

Tiedonhallinnassa hyvinvoinnin kokemusta heikentäväksi tekijäksi käsitetään suuren tietomäärän ja hoitotyön luonteen välinen haaste. Uutta tietoa tulee jatkuvasti runsaasti, ja sitä toisaalta myös kaivataan, mutta hoitotyössä ei aina jää riittävästi aikaa tiedon sisäistämiseen. Tiedon viestiminen ja sen mahdollistavat rakenteet kytkeytyvät työhyvinvointiin. Etenkin teknologiavälitteisesti jaettava tieto nähdään ongelmalliseksi, kun aikaa tietokoneen äärelle pysähtymiseen ei hoitotyön lomassa juuri ole ja suuresta tietomäärästä oleellisimman tiedon poimiminen voi olla haastavaa. Hoitohenkilöstö käsittää tiedon ylhäältä alaspäin annettuna, ikään kuin tuotteena, joka tulee organisaation ylemmiltä tasoilta henkilöstön 
omaksuttavaksi. Tiedon omaksuminen ja oppiminen kuvataan yksilön vastuiksi, mutta työyhteisön tai organisaation nähdään voivan tukea näitä prosesseja esimerkiksi kehittämällä ja tarjoamalla erilaisia käytänteitä tiedon jakamiseksi ja jalkauttamiseksi.

Organisaation ja työyhteisön mahdollistamista, tiedonhallintaa tukevista käytänteistä viikoittaista osastokokousta pidetään työhyvinvointia tukevana vuorovaikutuskäytänteenä. Osastokokouksissa organisaation suuresta tietomäärästä poimitaan käsiteltäväksi oleellisimmat asiat. Osastokokoukset käsitetään tiedottamisen areenoiksi, joissa kokemusta hyvästä voinnista tuottaa se, että joku muu - eli usein kokousta vetävä osastonhoitaja tai apulaisosastonhoitaja - on vastuussa tiedonhallinnasta. Hoitotyön luonteesta johtuvien tekijöiden nähdään kuitenkin hankaloittavan osastokokouksiin osallistumista ja siten tiedonhallintaa: Hoitohenkilöstö ei aina pääse osastokokouksiin hoitotyön limittyessä päällekkäin kokousten kanssa, ja vuorotyön vuoksi henkilöstölle voi tulla pitkiäkin taukoja, jolloin osastokokouksen aikana ei olla työpaikalla. Tiedonhallinnan lisäksi osastokokouksilla koetaan olevan yhteisöllisyyden kokemusta rakentava merkitys, sillä osastokokoukset ovat ainoita viikoittaisia ryhmätilanteita, joissa hoitajat ja hoitotyötä tukeva henkilöstö kokoontuvat yhtä aika yhteen.

Tiedonhallinnan merkityksissä korostuu näkemys hoitotyön arvopohjasta. Tiedonhallinta on tärkeää potilasturvallisuuden vuoksi, ja onnistunut tiedonhallinta voi edistää arvojen toteutumista työssä. Tiedonhallinnan haasteisiin kytkeytyy myös tiedon saamisen tasavertaisuus. Kun sama tieto ei ole kaikilla työyhteisön jäsenillä, epävarmuutta esimerkiksi omasta ammattitaidosta syntyy. Epävarmuus voi tuottaa kokemuksen hyvinvoinnin heikkenemisestä. Kokemus epätasa-arvoisesta tiedon jakamisesta aiheuttaa epävarmuutta myös yksilön omasta positiosta työyhteisössä, kuten seuraavassa aineistoesimerkissä jäsennetään:

H1: Kyllä mä aattelen että sillä [tiedolla] on osaltaan joku. En mä näe että sillä hirveän iso merkitys on, mutta kyllä se, että jos ne tiedot ei kulje, jos ne jää tietyn porukan tiedoks vaan, niin kyllä se vaikuttaa siihen työhyvinvointiinkin. Tavallaan se, että jos näät että joku tekee toisella tavalla jonkun asian, ja ite teet toisella tavalla ja mietit, että mikähän tässä mättää, miks mä teen näin ja sitten kuulee vähän että meillä on tullut tämmöstä infoa. Ja sit ite että "miksi mulle ei oo kukaan kertonu vaikka mä teen samaa työtä”. 


\section{Johtopäätökset}

Työhyvinvointi jäsentyi hoitohenkilöstön käsityksissä vuorovaikutuksessa rakentuvaksi ilmiöksi, jossa vuorovaikutuksen prosesseja ja ilmiöitä ei voida yksiselitteisesti luokitella myönteisiksi tai kielteisiksi, vaan molemmat ulottuvuudet voivat olla osa samaa prosessia tai ilmiötä. Työhyvinvoinnin kokemuksen rakentuminen vuorovaikutuksessa näyttäytyy jatkumoina, joissa samat prosessit tai ilmiöt voivat saada monenlaisia merkityksiä. Hoitohenkilöstön käsitykset työyhteisön vuorovaikutuksen merkityksestä työhyvinvoinnille jäsentyivät kategorioihin kuuluminen, yhteistyö, vaikuttaminen, tuki ja tiedonhallinta. Työhyvinvoinnin kokemuksen rakentumisen moniulotteisuudessa näkyy vuorovaikutuksen luonne: vuorovaikutus on jatkuva, dynaaminen prosessi, jossa luodaan ja muokataan sosiaalista todellisuutta (Littlejohn \& Foss 2008).

Aiemmissa tutkimuksissa kuulumisen tunteen on todettu edistävän työhyvinvointia. Hoitajien hyvinvoinnin rakentajiksi on nimetty esimerkiksi hoitajien yhteenkuuluvuus ja keskinäinen kollaboraatio (Utriainen ym. 2015). Tämän tutkimuksen tulokset näyttävät kuulumisen monitasoisena ilmiönä, joka ei aina kytkeydy hyvinvoinnin kokemuksen rakentumiseen. Ulkopuoliseksi jättäytyminen erilaisista työyhteisön ryhmistä voi olla yksilön oma valinta. Kuuluminen kytkeytyi tässä tutkimuksessa työhyvinvoinnin kokemuksen rakentumiseen vapaaehtoisuuden ja pakollisuuden ulottuvuuksilla: Jotkut haluavat jättäytyä vapaaehtoisesti vertaisryhmän ulkopuolelle, jolloin hyvinvoinnin kokemusta rakentaa vuorovaikutus, jossa yhteenkuuluvuutta tiettyihin ryhmiin ei ilmaista. Ulkopuolelle jättämisen ja jättäytymisen välillä on työhyvinvoinnin kokemuksen rakentumisen kannalta eroa.

Myös vaikuttamisen merkityksissä voidaan havaita samankaltaisia ulottuvuuksia vapaaehtoisuuden ja pakollisuuden välillä. Hoitohenkilöstö pitää vaikuttamisen mahdollisuuksia tärkeinä, mutta merkityksellistä hyvinvoinnin kokemuksen rakentumiselle voi olla myös se, että ei ole pakko vaikuttaa, vaan joku muu vaikuttaa ja kantaa vastuun muiden puolesta. Aiemmissa tutkimuksissa on todettu, että hoitohenkilöstön mahdollisuus vaikuttaa heidän omaan työhönsä luo tunteen työn hallinnasta, joka kytkeytyy hyvinvoinnin kokemuksen rakentumiseen (Breaux ym. 2008; Rodwell \& Munro 2013). Työhyvinvointia rakentavaan vuorovaikutukseen kytkeytyy myös "kuulemisen tunne", mahdollisuus tulla kuulluksi ja jakaa omia ajatuksiaan työyhteisössä (Utriainen 2009). Mahdollisuus tulla kuulluksi nivoutuu tämän tutkimuksen tulokseen mahdollisuudesta vaikuttaa tai toisaalta olla vaikuttamatta. Kokemus mahdollisuudesta 
vaikuttaa, saada äänensä kuuluviin, voi olla tärkeää hyvinvoinnin kannalta, vaikka mahdollisuutta ei itse kokisikaan tärkeäksi käyttää. Vaikutusmahdollisuuksille onkin löydetty myös muita kuin työhyvinvointia tukevia merkityksiä: Joensuun (2014) mukaan suuri päätäntävalta työssä on yhteydessä esimerkiksi kohonneeseen mielenterveysongelmien riskiin. Vaikuttamismahdollisuuksia työyhteisöissä kehitettäessä on tärkeää huomioida, että vaikutusmahdollisuuksien kasvattaminen ei automaattisesti lisää työhyvinvointia.

Tiedonkulku ja avoin tiedon jakaminen liitetään usein osaksi työhyvinvointia (esim. Luomala 2008; Vuorensyrjä 2008). Tässä tutkimuksessa tiedonhallinnan merkitykset jakautuivat jatkumolle, jossa nousee esiin toisaalta hoitohenkilöstön tarve saada runsaasti tietoa ja toisaalta hoitohenkilöstön kokemat tiedonhallinnan haasteet. Avoimen tiedonjakamisen sijaan hyvinvoinnin kokemuksen rakentumiseen kytkeytyy tämän tutkimuksen tulosten perusteella hyvin suunniteltu ja tarkoituksenmukaisesti toteutettu tiedonhallinta. Hoitohenkilöstö näkee tiedon nyt ylhäältä alaspäin annettavana tuotteena. Tiedon kollektiivisempi käsittely voisi tukea tiedonhallintaa yhteisötasolla. Jüngerin ym. (2007) mukaan kollektiivinen tiedonhallinta voi edistää yhteisen ymmärryksen rakentumista yhteisistä tavoitteista ja toimintatavoista sekä tukea työhön identifioitumista. Sairaalatyöyhteisössä esimerkiksi osastokokoukset ovat areenoita, joissa yhteisöllinen tiedon jalostaminen on mahdollista (Mikkola ym. 2014). Osastokokousten kaltaisilla käytänteillä, jotka mahdollistavat työntekijöiden kokoontumisen säännöllisesti yhteen yhteisten asioiden äärelle, voitaisiin tukea ja kehittää työyhteisön tiedonhallintaa ja siten edistää työhyvinvointia.

Yhteistyön merkityksissä nousi esiin työntekijöiden tasavertaisuus ja eriarvoisuus erityisesti lääkäri-hoitajasuhteen kontekstissa. Hoitajilla on tarve kokea olevansa työyhteisössä tasavertaisessa asemassa lääkäreiden kanssa, mutta tietyissä hoitotyötilanteissa tasavertaisuuden osoittamista ei nähdä merkitykselliseksi hyvinvoinnin kannalta. Hoitoalalla kliinisen työn vuorovaikutuskäytänteiden on kuitenkin todettu voivan siirtyä myös muihin työyhteisön vuorovaikutustilanteisiin (Apker ym. 2010). Työhyvinvoinnin kannalta olisikin tärkeää tunnistaa vuorovaikutuksen erityispiirteet sairaalatyöyhteisön erilaisissa konteksteissa: kliinisessä työssä toimivaksi koettu vuorovaikutus ei välttämättä rakenna hyvinvointia siirrettynä samanlaisena muihin työyhteisön vuorovaikutustilanteisiin, joissa tavoitteet ja odotukset ovat erilaisia. Tasapainoilu erilaisten työtilanteiden ja niissä ilmenevien vaatimusten, roolien ja tunteiden välillä ja rajapinnoilla voi kuormittaa hoitotyöntekijöitä (Apker ym. 2005). Työhy- 
vinvoinnin näkökulmasta on tärkeää tarkastella jatkossa monipuolisesti myös muita kuin hoitotyön vuorovaikutustilanteita. Esimerkiksi erilaiset hallinnolliset ryhmätilanteet, joissa työtä suunnitellaan, organisoidaan ja koordinoidaan, ovat työn tavoitteiden saavuttamisen kannalta keskeisiä (Pennanen \& Mikkola 2013) ja siten myös työhyvinvoinnin näkökulmasta kiinnostavia vuorovaikutustilanteita. Tämän tutkimuksen tulosten perusteella voidaan todeta, että myös työyhteisöjen diversiteettiin on syytä kiinnittää huomiota vuorovaikutuksessa rakentuvaa työhyvinvointia arvioitaessa tai kehittämään pyrittäessä. Esimerkiksi eri-ikäisillä ja -taustaisilla työntekijöillä voi olla erilaisia odotuksia, oletuksia ja arvostuksia työyhteisön vuorovaikutuksesta ja myös laajemmin työstä ja sen merkityksestä.

Tuen merkityksissä riittävä ja tarkoituksenmukainen emotionaalinen ja tiedollinen tuki rakensivat hyvinvoinnin kokemusta. Tiedollisen tuen merkityksissä liiallinen neuvominen nähtiin työntekijän ammattitaitoa kyseenalaistavaksi vuorovaikutukseksi, joka tuottaa pahoinvoinnin kokemusta. Utriainen (2009) on todennut työhyvinvoinnin osaksi yksilöllisyyden sallimisen, jolla tarkoitetaan esimerkiksi tekemisen vapautta: hoitajille on tärkeää kokea, että heidän omat yksilölliset työskentelytapansa sallitaan ja hyväksytään. Tuen merkityksissä tämän tutkimuksen tulosten voidaan tulkita kytkeytyvän samankaltaiseen sallivuuden tarpeeseen: ammatti-identiteetin vahvistamisen kannalta on merkityksellistä, että työyhteisössä osoitetaan luottamusta henkilöstön ammattitaitoa ja erilaisia toimintatapoja kohtaan. Toisaalta myös eri ammattiryhmien välisellä oppimisella voitaisiin saavuttaa etuja sairaalatyöyhteisössä.

Tutkimuksen tulokset osoittivat, että lääkäreiltä saatava palaute on tärkeää hoitohenkilöstön hyvinvoinnin kokemuksen rakentumisen kannalta. Aiemmat tutkimukset tukevat tätä tulosta palautteen merkityksestä (esim. Christiansen 2008). Lääkäreiltä saatava palaute voi olla osa oppimista ja kytkeytyä myös hoitajuuden arvostamiseen, joka on osa hoitajien työhyvinvointia (Utriainen 2009). Myös hoitajien mahdollisuus antaa palautetta lääkäreille voitaisiin nähdä oppimisen, yhteistyön laadun ja toisaalta myös työyhteisön tasavertaisuuden näkökulmasta hyödyllisenä. Tarkoituksenmukaisen palautevuorovaikutuksen mahdollistavia käytänteitä kehittämällä sairaalatyöyhteisön hyvinvoinnin rakentumista voitaisiin tukea.

Tämän tutkimuksen tulokset osoittivat, että hyvinvoinnin ja pahoinvoinnin kokemusta työyhteisön vuorovaikutuksessa rakentavat ilmiöt ja prosessit muodostuvat jatkumoiksi, joilla ne voivat saada erilaisia merkityksiä esimerkiksi kontekstin tai merkityksenantajan mukaan. Tulos jatkumoista kytkeytyy tuoreehkoon työvoinnin käsitteeseen. Työvointi ei tar- 
kastele vain työssä todentuvaa hyvinvointia tai pahoinvointia, vaan kattaa nämä molemmat. Työvoinnin käsitteessä myönteistä, kuten työn imua, ja kielteistä, kuten stressiä, ei nähdä toisistaan erillisinä, vaan pikemminkin toisiinsa kytkeytyvinä tekijöinä, jolloin niitä on myös syytä tutkia yhdessä. (Perttula 2011; Syväjärvi ym. 2012.) Työvoinnin käsitteen näkökulmaa hyödyntämällä jatkotutkimuksessa voidaan syventää ymmärrystä työhyvinvoinnista moniulotteisena ja dynaamisena ilmiönä, jossa vuorovaikutukselle annetut myönteiset ja kielteiset merkitykset voivat limittyä.

Tämä tutkimus osoitti, että vuorovaikutuksen ilmiöiden ja prosessien tarkasti rajattuihin hyvinvoinnin tai pahoinvoinnin luokkiin kategorisoinnin sijaan on tärkeää ymmärtää työhyvinvointia rakentavaa vuorovaikutusta jatkumoina, joita voidaan myös vuorovaikutuksessa hallita. Työvoinnin ja vuorovaikutuksen johtaminen työyhteisöissä ovatkin kiinnostavia jatkotutkimuksen kohteita. Tämän tutkimuksen tuloksista voidaan havaita, että sairaalatyöyhteisössä niin tehtävä- kuin suhdetasoon kytkeytyvä vuorovaikutus rakentaa hyvinvoinnin ja pahoinvoinnin kokemuksia. Hoitotyö on vahvasti tietoon pohjautuvaa työtä, jossa tehtävätason vuorovaikutuksen sujuvuudella on keskeinen merkitys työn laadun kannalta. Työssä ovat kuitenkin keskeisesti mukana myös erilaiset suhdetason ulottuvuudet. Hoitotyötä kuvataankin tunnetyöksi (emotion work, emotional labor), jossa työntekijät joutuvat jatkuvasti hallitsemaan tunteitaan. Tunteita hallitsemalla pyritään esimerkiksi luomaan hoitotilanteesta potilaalle turvallinen ja miellyttävä. (esim. Hochsild 1983; Karimi ym. 2014.) Emotionaalista kuormittavuutta hoitotyössä voivat aiheuttaa myös organisaatiosta tai jopa yhteiskunnasta kumpuavat lähtökohdat: hoitajilla on tarve vastata potilaiden tarpeisiin, mutta välillä tarpeisiin vastaaminen on mahdotonta käytössä olevilla rajallisilla resursseilla (Grønkjær 2013). Puheviestinnän tutkimuksella voitaisiin syventää ymmärrystä tunnetyön erityispiirteistä vuorovaikutuksen näkökulmasta. Ymmärrys vuorovaikutuksen keskeisestä merkityksestä ja sen moniulotteisuudesta työhyvinvoinnin kokemuksen rakentumisen prosesseissa on oleellista, jotta työhyvinvointia ja sen ylläpitämistä ja kehittämistä voidaan tukea muuttuvassa työelämässä ja erilaisissa työyhteisöissä.

\section{Tutkimuksen arviointi}

Aineiston uskottavuutta suhteessa tutkimustavoitteiseen arvioitaessa voidaan todeta, että tutkimuksen aineiston koko oli riittävä. Aineistonkeruussa ei ollut tavoitteena saturaatio, vaan pyrkimyksenä oli kerätä ai- 
neistoa, jossa nousee esiin hoitohenkilöstön käsitysten kirjo, käsitysten samanlaisuus tai erilaisuus. Aineistoa voidaankin pienehköstä koostaan huolimatta kuvata rikkaaksi. (ks. myös Mikkola ym. 2014.) Toki suuremmalla aineistolla oltaisiin voitu saavuttaa laajempi käsitysten kirjo. Myös haastateltavien laajempi ikäjakauma olisi saattanut tuottaa erilaisia tuloksia. Haastateltavista päätettiin käyttää yleisnimitystä hoitohenkilöstö, koska myös muiden kuin hoitoalan koulutuksen saaneiden työtehtävät kytkeytyivät tiiviisti hoitotyön tukemiseen. Analyysissa havaittiin, että haastateltavien käsitykset olivat samankaltaisia.

Analyysin luotettavuutta ja uskottavuutta pyrittiin lisäämään toteuttamalla analyysi systemaattisesti ja kuvaamalla analyysin eri vaiheet huolellisesti. Analyysimenetelmässä hyödynnettiin fenomenografisen analyysin näkemystä kokemuksesta. Analyysin laadun ja luotettavuuden arvioinnin varmistamiseksi analyysin kuvauksessa on oleellista raportoida analyysiprosessi riittävän läpinäkyvästi. Järjestelmällisesti toteutetun aineiston koodauksen lisäksi tässä tutkimuksessa pyrittiin raportoinnin avulla mahdollistamaan lukijalle analyysiprosessin läpinäkyvyys, jotta kategorioiden muodostumista ja analyysin lopputulokseen pääsemistä voidaan arvioida. (ks. Huusko \& Paloniemi 2006.)

Tutkimuseettiset näkökulmat huomioitiin läpi koko tutkimusprosessin. Haastateltavien itsemääräämisoikeudesta (Tutkimuseettinen neuvottelukunta 2009) huolehdittiin varmistamalla osallistujien vapaaehtoisuus: haastateltavilta pyydettiin kirjallinen suostumus haastattelun tallentamisesta ja käyttämisestä tutkimuksessa, ja heillä oli mahdollisuus kysyä tutkijalta lisätietoja sekä halutessaan vetäytyä tutkimuksesta missä tahansa tutkimuksen vaiheessa. Yksityisyyden ja tietosuojan periaate (Tutkimuseettinen neuvottelukunta 2009) huomioitiin huolehtimalla haastateltavien anonymiteetistä. Haastateltavat saivat itse valita haastatteluajan ja -paikan. Haastattelua ei siis tarvinnut toteuttaa työpaikan tiloissa työaikana, jolloin haastateltavien anonymiteetti oli mahdollista säilyttää myös työyhteisön sisällä. Aineistoesimerkeistä jätettiin pois yksityiskohdat, joista haastateltavan tai työyksikön voisi tunnistaa. Vahingoittamisen välttämisen periaate (Tutkimuseettinen neuvottelukunta 2009) huomioitiin pyrkimällä pitämään tutkimuksesta aiheutuva kuormitus tutkittaville mahdollisimman vähäisenä sekä osoittamalla arvostusta tutkittavia kohtaan niin aineistonkeruussa kuin aineiston analyysissa ja tulosten raportoinnissa. 
Artikkeli perustuu tekijän väitöskirjatutkimukseen, jonka ohjaajana toimii yliopistonlehtori, FT Leena Mikkola Jyväskylän yliopistosta. Tutkimusta ovat tukeneet Jyväskylän yliopisto ja Työsuojelurahasto (hanke 112304 Sairaalatyöyhteisön työhyvinvointia rakentavat vuorovaikutuskäytänteet).

\section{Kirjallisuus}

Ang, S. H., Bartram, T., McNeil, N., Leggat, S. G. Stanton, P. 2013. The effects of high-performance work systems on hospital employees' work attitudes and intention to leave: A multi-level and occupational group analysis. The International Journal of Human Resource Management 24 (16), 3036-3114.

Anttonen, H. \& Räsänen, T. (toim.) 2009. Työhyvinvointi - uudistuksia ja hyviä käytäntöjä. Helsinki: Työterveyslaitos.

Apker, J. 2012. Communication in Health Organizations. Campridge, UK: Polity.

Apker, J., Mallak, L. A., Applegate, E. B., Gibson, S. C., Ham, J. J., Johnson. N. A. \& Street, R. L. 2010. Exploring emergency physicianhospitalist handoff interactions: Development of the handoff communication assessment. Annals of Emergency Medicine 55 (2), $16-70$.

Apker, J., Propp, K. M. \& Ford, W. S. 2005. Negotiating status and identity tensions in healthcare team interactions: An exploration of nurse role dialectics. Journal of Applied Communication Research 33 (2), 93-115.

Ashker, V., Penprase, B. \& Salman, A. 2012. Work-related emotional stressors and coping strategies that affect the well-being of nurses working in hemodialysis units. Nephrology Nursing Journal 39 (3), 231-237.

Barbour, J. B. 2010. On the institutional moorings of talk in health care organizations. Management Communication Quarterly 24 (3), 449-456.

Breaux, D. M., Meurs, J. S., Zellars, K. L. \& Perrewe, P. L. 2008. Burnout in health care: When helping hurts. Teoksessa J. R. B. Halbesleben (toim.) Handbook of stress and burnout in health care. New York: Nova Science Publishers, 39-50.

Christiansen, B. 2008. Good work - how is it recognised by the nurse? Journal of Clinical Nursing 17 (12), 1645-1651. 
Dackert, I. 2010. The impact of team climate for innovation on well-being and stress in elderly care. Journal of Nursing Management 18 (3), 302-310.

Flinkman, M. 2014. Young Registered Nurses' Intent to Leave the Profession in Finland. A Mixed-method Study. Sarja D, osa 1107, Medica-odontologica. Turku: Turun yliopisto.

Friese, S. 2014. Qualitative Data Analysis with ATLAS.ti. 2. painos. Lontoo: Sage.

Grønkjær, L. L. 2013. Nurses' experience of stress and burnout: A literature review. Klinisk Sygepleje 27 (1), 15-26.

Gurková, E., Čáp, J., Žiaková, K. \& Ďurišková, M. 2012. Job satisfaction and emotional subjective well-being among Slovak nurses. International Nursing Review 59 (1), 94-100.

Hakanen, J. 2005. Työuupumuksesta työn imuun: työhyvinvointitutkimuksen ytimessä ja reuna-alueilla. Työ ja ihminen, tutkimusraportti 27. Helsinki: Työterveyslaitos

Hakanen, J. J., Bakker, A. B., \& Jokisaari, M. 2011. A 35-year follow-up study on burnout among Finnish employees. Journal of Occupational Health Psychology 16 (3), 345-360.

Hasselgren, B. \& Beach, D. 1997. Phenomenography - a "good-fornothing brother" of phenomenology? Outline of an analysis. Higher Education Research \& Development 16 (2), 191-202.

Hayes, B., Bonner, A. \& Pryor, J. 2010. Factors contributing to nurse job satisfaction in the acute hospital setting: a review of recent literature. Journal of Nursing Management 18 (7), 804-814.

Hochscild, A. R. 1983. The Managed Heart: Commercialization of Human Feelings. Berkeley, CA: University of California Press.

Huusko, M. \& Paloniemi, S. 2006. Fenomenografia laadullisena tutkimussuuntauksena kasvatustieteissä. Kasvatus 2/2006, 162-173.

Joensuu, M. 2014. Job control as a Predictor of Mental and Cardiovascular Health - a Prospective Multicohort Study. Työ ja ihminen, tutkimusraportti 106. Helsinki: Työterveyslaitos.

Jones, M. C., Wells, M., Gao, C., Cassidy, B. \& Davie, J. 2013. Work stress and well-being in oncology settings: a multidisciplinary study of health care professionals. Psycho-Oncology 22 (1), 46-53.

Jünger, S., Pestinger, M., Elsner, F., Krumm, N. \& Radbruch, L. 2007. Criteria for successful multiprofessional cooperation in palliative care teams. Palliative Medicine 21 (4), 347-354. 
Järvinen, P. \& Järvinen, A. 2011. Tutkimustyön metodeista. Tampere: Opinpajan kirja.

Kanste, O. 2011. Work engagement, work commitment and their association with well being in health care. Scandinavian Journal of Caring Sciences 25 (4), 754-761.

Karimi, L., Leggat, S. G., Donohue, L., Farrell, G. \& Couper, G. E. 2014. Emotional rescue: the role of emotional intelligence and emotional labour on well-being and job-stress among community nurses. Journal of Advanced Nursing 70 (1), 176-186.

Krueger, L., Funk, C., Green, J. \& Kuznar, K. 2013. Nurse-related variables associated with patient outcomes: A review of the literature 2006-2012. Teaching and Learning in Nursing 8 (4), 120-127.

Lindlof, T. R. \& Taylor, B. C. 2002. Qualitative Communication Research Methods. 2. painos. Thousand Oaks, CA: Sage.

Littlejohn, S. W. \& Foss, K. A. 2008. Theories of Human Communication. 9. painos. Belmont, CA: Thomson Wadsworth.

Lu, H., Barriball, L., Zhang, X. \& While, A . E. 2012. Job satisfaction among hospital nurses revisted: A systematic review. International Journal of Nursing Studies 49 (8), 1017-1038.

Luomala, A. (toim.) 2008. Työhyvinvointi muutoksessa. Tutkimus kuntaliitoksen vaikutuksesta henkilöstön työhyvinvointiin. Turkimushankkeen loppuraportti osa 1.Tampereen yliopiston kauppakorkeakoulu, Synergos.

Marton, F. \& Pong, W. Y. 2005. On the unit of description in phenomenography. Higher Education Research \& Development 24 (4), 335-348.

Melo, M. B., Barbosa, M. A. \& Souza, P. R. 2011. Job satisfaction of nursing staff: integrative review. Revista Latino-Americana de Enfermagem 19 (4), 1047-1055.

Mikkola, L., Pennanen, E., Laapotti, T. \& Välipakka, H. 2014. Sairaalatyöyhteisön työhyvinvointia rakentavat vuorovaikutuskäytänteet. Tutkimushankkeen loppuraportti (Työsuojelurahaston hanke 112304). Jyväskylä: Jyväskylän yliopisto.

Nakakis, K. \& Ouzouni, C. 2008. Factors incluencing stress and job satisfaction of nurses working in psychiatric units: A research review. Health Science Journal 2 (4), 183-195.

Pennanen, E. \& Mikkola, L. 2013. Vuorovaikutus hallinnollisissa ryhmissä. Hallinnon Tutkimus 32 (3), 229-242. 
Perttula, J. 2011. Työvoinnin johtaminen yliopistoyhteisössä. Teoksessa A. Lauriala, P. Naskali, S. Tuovila (toim.) Työtä rakkaudella rakkaudesta tiedettä. Lapin yliopiston kasvatustieteellisiä julkaisuja 26. Rovaniemi: Lapin yliopisto, 79-95.

Ray, E. B. \& Apker, J. 2011. Stress, burnout, and supportive communication. A Review of research in health organizations. Teoksessa T.R. Thompson, R. Parrot \& J. F. Nussbaum (toim.) The Routledge Handbook of Health Communication. 2. painos. New York, NY: Routledge, 428-440.

Rodwell, J. \& Munro, L. 2013. Well-being, satisfaction and commitment: The substitutable nature of resources for maternity hospital nurses. Journal of Advanced Nursing 69 (10), 2218-2228.

Rose, A. J. 2002. Co-rumination in the friendships of girls and boys. Child Development 73 (6), 1830-1843.

Shier, M. \& Graham, J. 2011. Work-related factors that impact social work practitioners' subjective well-being: Well-being in the workplace. Journal of Social Work 11 (4), 402-421.

Syväjärvi, A., Lehtopuu, H., Perttula, J., Häikiö, M. \& Jokela, J. 2012. Inhimillisesti tehokas sairaala - työn mielekkyys henkilöstön kokemana. Rovaniemi: Lapin yliopistokustannus.

Tourangeau, A., Patterson, E., Rowe, A., Saari, M., Thomson, H., MacDonald, G., Cranley, L. \& Squires, M. 2014. Factors influencing home care nurse intention to remain employed. Journal of Nursing Management 22 (8), 1015-1026.

Tulevaisuuden terveydenhuolto 2022. Sosiaali- ja terveysministeriö. 2010. <http://www.sitra.fi/julkaisut/muut/Tulevaisuuden $\% 20$ terveydenhuolto2022.pdf $>$. Viitattu 17.9.2015.

Tutkimuseettinen neuvottelukunta. 2009. Humanistisen, yhteiskuntatieteellisen ja käyttäytymistieteellisen tutkimuksen eettiset periaatteet ja ehdotus eettisen ennakkoarvioinnin järjestämiseksi. Helsinki: Tutkimuseettinen neuvottelukunta. <http://www.tenk.fi/sites/ tenk.fi/files/eettisetperiaatteet.pdf >. Viitattu: 26.9.2015.

Utriainen, K. 2009. Arvostava vastavuoroisuus ikääntyvien sairaanhoitajien työhyvinvoinnin ytimenä hoitotyössä. Oulun yliopisto. Acta Universitatis Oluensis D Medica 1014.

Utriainen, K., Ala-Mursula, L. \& Kyngäs, H. 2015. Hospital nurses' well-being at work: a theoretical model. Journal of Nursing Mangement 23 (6), 736-743.

Utriainen, K. \& Kyngäs, H. 2009. Hospital nurses' job satisfaction: a literature review. Journal of Nursing Management 17 (8), 1002-1010. 
Vuorensyrjä, M. 2008. Työn jättämisen vakava harkinta vanhusten ja vammaisten perushoitotyössä: komparatiivinen tutkimus Suomessa, Ruotsissa, Norjassa ja Tanskassa. Työelämän tutkimus 6 (3), 263-279.

Wiili-Peltola, E. 2005. Sairaala muutosten ristipaineessa. Hallinnan kehittämisen haasteita sairaalaorganisaatiossa. Tampereen yliopisto: Haus kehittämiskeskus.

Zhang, M., Zhu, C., Dowling, P. J. \& Bartram, T. 2013. Exploring the effects of high-performance work systems (HPWS) on the work-related well-being of Chinese hospital employees. International Journal of Human Resource Management 24 (16), 3196-3212. 